Fig.

3.-Inland cliff or escarpment of coral rock about $1 \frac{1}{2}$ miles north-west of Gay's Cove, standing at an elevation of about 100 feet above sea-level. At the foot of the cliff are masses of coral rock some of them fallen from the cliff, undercut by the sea at some later period. The coast eroded platform is now occupied by sugar-cane fields.

4.- View from Gay's Cove looking south-east towards Pico Teneriffe. In the foreground thick globigerina chalks of the Oceanic Series dip to the east; on the opposite side of the bay they are overlain by old weathered coral rock at the base of which is a bed of conglomerate of white limestone pebbles.

\title{
Puate IV.
}

1.-Scapharca cf. Deshayesi Hanl. var. 2. Right valve, three-quarters natural size. Rouen Village. 150 feet altitude.

2.-Pecten (Chlamys) cf. irradians Lam. Slightly reduced, Lower coral rock near Consett Point.

3.-Chione paphia Linn. cf var. Christopheri Trechm. Reduced. Rouen Village.

4.-Cyclina near C. subquadrata Hanley. Slightly reduced. Rouen Village.

5.-Codakia orbicularis Linn. var. Two-thirds natural size. Savannah near Bridgetown. Abont 40 feet elevation.

6.-Chione multicostata Sow. var. Left valve about one-half natural size. Rouen Village. 150 feet altitude.

7.-Chione cancellata Linn, a variety resembling the Bowden species C. Woodwardi Guppy. Three-quarters natural size. Base of Coral Rock near Gay's Cove.

8.-Calyptra (Mitruiaria) cf. Dillwynii Grav. Reduced. A specimen from 10 feet altitude at St. Lawrence near Hastings.

9.-Ditto, a cast from Canefield 1,000 feet altitude.

10.-Voluta musica Linn. var. One-half natural size. From Hastings about 20 feet altitude.

11.-Strombus pugilis Linn. var. with few spines on body whorl. About two-fifths natural size. Low levels near Bridgetown.

12 and 13.-Coralliophila Barbadensis. Sp. nov. About natural size, from low level coral rock near Hastings.

14.-Murex (Haustillum) messorius Sow. Slightly reduced, from Jow level coral rock near the west coast.

15, 16, 17.-Bulla, of. Vendryesiana Guppy. Slightly reduced. Figs 15 and 16 from low level coral rock near Hastings, Fig. 17 from basal coral rock at Gay's Cove.

18. - Bulla striata Brug or B. maculosa Mart. Recent from Barbados to show the shorter aperture and less everted aperture and callosity than in the fossil form.

\section{CORRESPONDENCE.}

\section{ASSIMILATION OF LIMESTONE AT LOCH BOROLAN.}

SrR,-In the Summary of Progress of the Geological Survey for 1930, Dr. J. Phemister has a short note on a carbonate rock occurring at Bad na h'Achlaise, Sutherlandshire, which I described in 1910. The rock appears in association with melanite-pyroxenite ("cromaltite "), and in my inexperience I took it to be a limestone which had been metamorphosed by contact with the latter rock. 
Dr. Phemister now shows that the carbonate rock is an alterationproduct of the cromaltite-a perfectly likely conclusion with which I have no wish to quarrel. But when he claims that this "removes the only piece of direct evidence which has so far been advanced in favour of assimilation of limestone in the Cnoc-na-Sroine (Loch Borolan) laccolite" he goes too far and too fast. He adds that in a recent paper of mine (Geol. MaG., 1930, 415) I quoted the Bad na h'Achlaise locality as one where there is "clear evidence of desilication of magma by limestone ". Neither in my 1930 paper, nor in my 1910 paper did I make any such claim about Bad na h'Achlaise. What I did claim is that in the Loch Borolan area as a whole, there is such evidence. Whether it is "direct" or not. is a question of definition; does Dr. Phemister expect me to show him a hot magma making a meal of limestone before he will be convinced?

The evidence of assimilation of limestone at Loch Borolan may be summarized as follows :-

(1) The Cnoc-na-Sroine complex as a whole is intrusive in the Durness Limestone, and is believed to have a limestone floor. This was the opinion of Horne and Teall, and it has not so far been questioned. Limestone is exposed all round the hill, although actual contact is only seen at a few points on the north and east. In addition, a rock which I took to be a metamorphosed limestone has been brought up along a thrust-plane between syenite and borolanite in the stream Aultivullin.

(2) All the rocks that are seen in contact with limestone, and all those that lie nearest to the supposed floor of the laccolith, are rich in melanite and diopside (" aegirine-augite").

(3) Diopside is a characteristic product wherever magnesian limestone becomes silicified at an igneous contact. Melanite is an uncommon mineral of which almost every known example occurs at a limestone contact.

(4) Granitic magmas like that of Cnoc-na-Sroine do not give rise to melanite-syenites and diopside-melanite rocks without some very special and local cause. The days are past when one could talk vaguely of " magmatic differentiation" and hope to get away with it. The only conceivable reason that anybody has ever been able to suggest for the development of the melanite rocks at Loch Borolan is assimilation of limestone, and there is no theoretical or factual objection to the suggestion.

Dr. Phemister is right to be critical, but in this instance I think he is being captious.

Stellenbosch, S. Africa.

S. J. SHAND.

18th April, 1932. 